Sylwia Gwiazdowska-Stańczak, PhD https:// orcid.org/ 0000-0002-4664-881X

Department of Psychology,

The John Poul II Catholic University

of Lublin

\title{
School engagement and school climate of students with high and low grade point averages
}

\author{
Zaangażowanie w naukę i klimat w szkole uczniów \\ z wysoką i niską średnią ocen \\ https:// doi.org/10.34766/fetr.v48i4.974
}

\begin{abstract}
For adolescents, school life and learning is one of the most important domains of their lives. School achievement, depending on whether it is high or low, can motivate students to learn or make them reluctant to engage in school learning. Students' engagement in learning is closely related to their perceived school climate. The present study set out to investigate how these two variables distinguish between groups of students with high and low grade point averages. The participants in this study were students from secondary schools from among whom the students with the lowest and the highest grade point average were selected. It is found that students with higher grade point average are more engaged in learning and perceive their school climate as more positive than students with low grade point average.

Keywords: learning engagement, school climate, grade point average, adolescents, school achievement

Abstrakt: Dla adolescentów życie szkolne i nauka są jednym z ważniejszych obszarów ich życia. Osiągnięcia szkolne w zależności czy są wysokie lub niskie mogą motywować do nauki lub sprawiać, że uczniowie nie chcą się angażować $\mathrm{w}$ naukę szkolną. Zaangażowanie uczniów w naukę ściśle związane jest $\mathrm{z}$ postrzeganym przez nich klimatem $\mathrm{w}$ szkole. $\mathrm{W}$ niniejszych badaniach postanowiono sprawdzić jak te dwie zmienne różnicują grupy uczniów z wysoką i niską średnią ocen. $W$ badaniach udział wzięli uczniowie ze szkół ponadpodstawowych spośród których wyodrębniono tych z najniższą i najwyższą średnią ocen. Okazuje się, że uczniowie z wyższą średnią ocen są mocniej zaangażowani $\mathrm{w}$ naukę i postrzegają klimat $\mathrm{w}$ swojej szkole jako bardziej pozytywny niż uczniowie $\mathrm{z}$ niską średnią ocen.
\end{abstract}

Słowa kluczowe: zaangażowanie w naukę, klimat w szkole, średnia ocen, adolescenci, osiągnięcia szkolne

\section{Introduction}

The school environment is one of the most important for the development of a youth, their main activity during adolescence is gaining knowledge and overcoming successive levels of education. Their education, knowledge and skills will determine their future getting to college, taking up a career. School achievements and memories of unique school climate, teacher support and relations with peers shape a teenager personality, self-esteem, 
self-assessment and self-efficacy (Høigaard, Kovac², Øverby \& Haugen, 2015). To understand the mechanisms that make some students feel better at school and more engaged in learning has not been explored in the Polish research field widely. Learning engagement is a more comprehensive concept than motivation and is described in terms of its three components-cognitive, behavioural and emotional engagement (Lam, Jimerson, Wong, Kikas, Shin, Veiga, Hatzichristou, Polychroni, Cefai, Negovan, Stanculescu, Yang, Liu, Basnett, Duck, Farrell, Nelson \& Zollneritsch, 2016). Research shows that factors such as a student's attitude toward school and the support provided there play a major role in shaping engagement. The way a student perceives his or her teacher and a positive relationship with him or her may prove to be the key to his or her educational success. For this reason, the more engaged a young person is in learning, the better grades he or she will receive. The more passionate and well-intentioned a young person is, the more initiative he or she will take for school life. What contributes to a positive perception of one's school and makes students eager to attend it is a positive school climate. It is characterized by interpersonal relationships between students and teachers, between peers, by equitable school rules and by opportunities for students to develop their passions and goals (Zullig, Collins, Ghani, Patton, Hunter, \& Scott Huebner, 2014).

\section{Engagement in learning and school climate}

Engagement in learning is captured as a broader element of motivation a metaconstruct encompassing various dimensions of engagement in school activities and commitment to learning (Skinner, Pitzer, \& Steele, 2016). Learning engagement is described along three dimensions-emotional engagement, cognitive engagement, and behavioral engagement. Emotional engagement are feelings associated with learning and the school environment. They can be both positive and negative. A student may be interested in learning which is related to his or her intrinsic motivation, have a sense of connectedness to the school. They may feel attached to school or conversely feel bored and unwilling to attend. Cognitive engagement is about the cognitive learning strategies a student chooses. Students with high cognitive engagement have a better understanding of their internal processes for understanding and remembering the material they are learning. Behavioral engagement refers to the effort and persistence a student expends on schoolwork. Students with high behavioural engagement learn intensively and are keen to engage in additional activities (Lam, et al. 2016; Gwiazdowska-Stańczak, 2021).

Engagement in learning is an active attitude toward school activities (Fredricks, Filsecker, \& Lawson, 2016). It is one of the strongest predictors of student success, high achievement, class attendance, and persistence in school (Poorthuis, Juvonen, Thomaes, Denissen, Orobio de Castro, \& van Aken, 2015). Researchers emphasize that engagement 
consists of different components-behavioral and emotional engagement (Skinner, Pitzer \& Steele, 2016) and cognitive engagement (Lam et. al. 2016). Engagement in learning is one of the most important areas of a student's performance in school. It determines his achievement, his participation in lessons and his obstinacy - even if he receives a worse grade, he is motivated to correct it. It represents determination, the effort a student invests in his or her education. What is important, engagement in learning protects young people from destructive behaviors such as skipping classes or using drugs. (Lippman \& Rivers, 2008; Liang, Rocchino, Gutekunst, Paulvin, Melo Li, \& Elam-Snowden, 2020).

School climate is shaped by teacher-student relationships, clear and understandable school procedures, and explicit instructions about the form of passing, test taking, and assignment completion. It is the student's subjective experience of the lived experiences of the school. Each school creates its own unique climate, norms, values and goals. (Zullig, Collins, Ghani, Patton, Hunter, \& Scott Huebner, 2014; Daily, Mann, Kristjansson, Smith, \& Zullig, 2019). Lower grades and academic achievement are attributed to students' own problems- laziness and disengagement in learning. Nevertheless, teachers' attitudes, their relationships with their students and the school climate they create can have a tremendous impact on improving student achievement (Reyes, Brackett, Rivers, White \& Salovey, 2012).

School climate is a very comprehensive concept. According to several authors, school climate is defined as the quality and character of school life that includes norms, values and expectations that make students feel safe at school and that satisfy their social and emotional needs (Martinez, Coker, McMahon, Cohen, \& Thapa, 2016). According to the researchers, school success, high academic engagement and low levels of aggression at school (bullying, cyberbulling, bullying of weaker students, vandalism, verbal and physical aggression) are also responsible for a positive school climate. A positive school climate also includes discipline, demands teachers make of students, and relationships with teachers. (Malone, Cornell i Shukla, 2016). School climate is defined as the characteristics and quality of school life, which include shared goals and values, the organisational structure of the school and, of course, the quality of interpersonal relationships between students and teachers (Clifford, Menon, Gangi, Condon \& Hornung, 2012).

\section{School Achievements}

School is one of the most important environments for adolescent development. This institution has not only didactic but also upbringing functions. The teacher plays an important role in the process of formation of a student's self-esteem. School is also a place to experience and be in a group of peers, which gives the opportunity to develop social competence and compare oneself with others. It is also the main place that provides opportunities for youth to demonstrate themselves through school achievements, grades, 
awards, and praise. The topic of high school achievement raises many problems for researchers. First of all, it is difficult to define and distinguish certain terms - such as gifted student, outstanding student, student with outstanding achievements, creative student, etc. Another problem is clear achievement criteria. The criteria of achievement include both measurable school success such as high average, results in tests and Olympiads, as well as standardized methods for measuring creativity, intelligence, or motivation. Many factors influence a student's success in school. High intelligence, creativity, and personality factors are considered predictors of high achievement. Of course, the environment in which a young person develops is also important - his/her family, the school he/she participates in and peers' contacts (Gwiazdowska-Stańczak \& Sękowski, 2018; Sękowski \& GwiazdowskaStańczak, 2019). The factor that determines students' school progress is the didactic and pedagogical work of the school and the teacher. While acknowledging their significant impact on students' academic progress, it is important to note that they are both numerous and varied. The most important include: the content of the form, methods and means of upbringing and teaching, and in addition, the conditions in which the work of teaching and education takes place, such as one- or two-shift teaching, the size of the class, a certain level of professional qualifications of teachers and their social position. The failure of children to make progress in learning is also greatly influenced by the personality of the teacher, his/her mental and moral level, his/her behaviour, and the methods of education and teaching he/she uses. The lack of learning progress is related to the content or organization or methods and means of teaching and upbringing. They mainly concern the overload of programs that require children to work beyond their strength (Ferreira, Martinsone, \& Talić, 2020).

The didactic causes that can affect students' school achievement include the curriculum content, the organizational conditions of the school and the teacher's working methods. When the curriculum is not sufficiently adapted to the mental abilities of children at a given age of life, when the curriculum is not adequately adapted to the mental capacities of children at a given age, many difficulties arise in the children's learning process, the accumulation of which sometimes leads to overt school failure. Another drawback of curricula, which is pointed out in the research on the causes of school failure, is their overload. In addition, curricula tend to be tailored to the abilities of average-ability children (Holmberg, 2020).

The results of the teaching process also depend on the teacher, the methods and tools of his work. The program, school equipment, pedagogical and general knowledge of the teacher are the tools of his didactic work. The specific course of the teaching process is determined by the teacher's professional qualifications, attitude to work and personality traits. Getting to know the students and properly directing their learning, frequent control of their knowledge and supervision of the course of their work, as well as organizing the work 
of individual students and groups are the conditions for success in didactic work. In the school environment, the most important and valued skill of teachers is the accurate recognition of the level of student achievement and its reliable and objective assessment. It is the teacher's responsibility to choose the content, form, and process of student evaluation. Assessment is a multi-faceted and complex process that involves making judgments about students through grades, descriptive assessments, or examinations. Information about student achievement is essential to the development of flexible learning activities and is a key element in motivating students to learn. (Ferreira, Martinsone \& Talić, 2020).

In consideration of the theoretical assumptions regarding academic engagement and school climate and the specific characteristics of students with higher and lower school achievement, the following research question was posed:

1. Are students with higher grade point averages going to differ from students with low grade point averages in terms of engagement in learning and school climate?

Based on the literature and previous research, the following hypotheses were generated:

1. Students with higher grade point averages will be more engaged in learning.

2. Students with higher grade point averages will have a more positive perception of their school climate.

\section{Methods}

A total of 590 students from secondary schools participated in the study, using quarter deviation analysis, students with a mean of 3.3 (146 students) were classified into the group with low mean scores and students with a mean of 5.2 (143 students) into the group with high mean scores. The respondents were in the age range of 14-18 years, gender distribution was equally distributed. Most of the students come from cities, most of their parents have secondary or higher education and most of them are working people. The study was conducted through an online survey, the link was given through the teachers after receiving permission for the study. The respondents were informed about anonymity and voluntary participation in the study. Two methods were used:

Engagement in learning was measured using a scale by Lam, Wong, Shin, Hatzichristou, Negovan, Stanculescu, Liu, Duck, Nelson, Jimerson, Kikas, Veiga, Cefai, Yang, Basnett, Farrell, Zollneritsch. The method contains 33 items that are answered on a 5point scale (from 1-strongly disagree to 5-strongly agree). Engagement in learning is understood here as a meta-construct that includes multiple dimensions of attachment to school and engagement in learning. The method consists of three scales: Emotional Engagement Scale (9 items) includes sense of belonging, identification with school, level of interest in learning, feelings about learning. Behavioral Engagement Scale (12 items) includes 
effort and persistence in school work, class participation, attendance, task completion. The Cognitive Engagement Scale (12 items) includes learning strategies and styles (Lam, i in., 2014).

School climate was measured using the latest version of "The School Climate Measure (SCM)". It is a method by Zullig, Ghani, Patton, Collins, Hunter, Huebner. The questionnaire has 50 items and 10 (factor) scales. Respondents give answers for the first 8 items on a 6-point scale, for the rest on a 5-point scale). School climate is understood here as a student's subjective experience, related to his/her sense of security, experience of school life. The method includes the following scales: The student's positive relationship with the teacher (8 items) is the teacher's degree of interest in the student's affairs, the student's future, the teacher's devotion to the student's time, the teacher's helpfulness and sympathy, Precepts and discipline (6) is the student's sense that school rules apply equally to all students, his or her sense of fairness in school, Opportunity and commitment to learning(6) is the student's sense that all are treated equally and equally likely to succeed, School environment (4) means that the school is orderly and kept clean, Support for learning (4) means clear expectations placed on students, that, that they understand their homework and that teachers have equal expectations for all students, Parental involvement (3) parents talk to teachers about the school, are involved in school life and the curriculum, Attitudes toward school (4) means that school is exciting and interesting, makes students want to Observance of rights and responsibilities (3) means that all students know their rights and responsibilities and that these are respected, Social environment at school (2) is satisfaction with relationships with other students at school, Satisfaction with learning (2) describes student satisfaction with the number of tests and homework (Zullig et al., 2015).

Grade point average is one of the most commonly used criteria for assessing students' academic achievement. In this study, this criterion was used to distinguish between two extreme groups of students-those with the highest grade point average and those with the lowest, in other words, gifted and less gifted students. It was hypothesized that gifted students with better grade point averages are those who are more engaged in learning and who rate their school climate as more positive.

\section{Results}

Table 1 presents the Pearson's $r$ correlation coefficients for the study variablesengagement in learning and school climate. Perceived school climate is closely related to student engagement in learning. The only climate scale that does not correlate only with cognitive engagement and the other dimensions and the total score does not is the respect for rights and responsibilities scale. The strongest relationship is for the overall school climate score with emotional engagement. Learning engagement positively correlates with most of 
the school climate scales. The highest correlation coefficients are found with the emotional engagement dimension, which is most strongly positively related to the student's positive relationship with the teacher, attitude toward school, learning support, precepts and discipline, and satisfaction with learning and opportunities. School climate is strongly related to engagement in learning, and this relationship can be two-way, in that both a good school climate makes students more eager to learn and more active in class and, on the other hand, students who are engaged in school life and learning improve school climate. The better students perceive their school and their relationship with teachers who are supportive and fair, the better the environment for developing students' learning potential. School climate is most strongly associated with emotional engagement, or a sense of belonging and identification with one's school. There is a great sense of enjoyment in attending class that translates into positive emotions about learning and working in the classroom. Attitudes toward school, teacher support, and self-confidence correlate most strongly with behavioral engagement. A student who believes that he or she can succeed in this particular class, educational institution will be more motivated and will make greater physical effort to achieve his or her goals. The more interesting and exciting the lessons are the more willing students are to participate. Young people do not need to be persuaded to go to a class that they are keenly interested in. Spending a lot of time studying or doing homework that is intriguing will not be a problem. The lowest correlation coefficients are for the involvement relationship with the parent involvement scale. It is important to note here the developmental stage of the study - the subjects were adolescents who are experiencing an identity crisis at this time and very often defy their parents' opinion in search of their own path. Summarizing the relationship between engagement and school climate, it might be pointed out that learning motivation is most strongly influenced by the school environment and teachers, and to a much greater extent by parents and other external factors.

Table 1. Correlations of school climate with engagement in learning

\begin{tabular}{|c|l|l|l|l|}
\hline $\begin{array}{l}\text { School climate } \\
(\mathrm{N}=590)\end{array}$ & $\begin{array}{l}\text { Emotional } \\
\text { engagement }\end{array}$ & $\begin{array}{l}\text { Behavioural } \\
\text { engagement }\end{array}$ & $\begin{array}{l}\text { Cognitive } \\
\text { engagement }\end{array}$ & $\begin{array}{l}\text { School engagement } \\
\text { Overall result }\end{array}$ \\
\hline Overall result &, $705^{* *}$ &, $577^{* *}$ &, $573^{* *}$ &, $698^{* *}$ \\
\hline $\begin{array}{c}\text { Positive Student- } \\
\text { Teacher } \\
\text { Relationships }\end{array}$ &, $628^{* *}$ &, $587^{* *}$ &, $620^{* *}$ \\
\hline $\begin{array}{c}\text { School } \\
\text { Connectedness }\end{array}$ &, $703^{* *}$ &, $521^{* *}$ &, $526^{* *}$ &, $682^{* *}$ \\
\hline $\begin{array}{c}\text { Academic Support } \\
\text { Order and } \\
\text { Discipline }\end{array}$ &, $605^{* *}$ &, $417^{* *}$ &, $451^{* *}$ &, $623^{* *}$ \\
\hline $\begin{array}{c}\text { School Physical } \\
\text { Environment }\end{array}$ &, $416^{* *}$ &, $374^{* *}$ &, $411^{* *}$ &, $455^{* *}$ \\
\hline
\end{tabular}




\begin{tabular}{|c|l|l|l|l|}
\hline $\begin{array}{c}\text { School Social } \\
\text { Environment }\end{array}$ &, $490^{* *}$ &, $415^{* *}$ &, $429^{* *}$ &, $494^{* *}$ \\
\hline $\begin{array}{c}\text { Perceived } \\
\text { Exclusion/Privileg } \\
\mathrm{e}\end{array}$ &, 071 &, 029 &, $085^{*}$ &, 070 \\
\hline $\begin{array}{c}\text { Academic } \\
\text { Satisfaction }\end{array}$ &, $563^{* *}$ &, $401^{* *}$ &, $424^{* *}$ &, $520^{* *}$ \\
\hline $\begin{array}{c}\text { Parental } \\
\text { Involvement }\end{array}$ &, $358^{* *}$ &, $388^{* *}$ &, $292^{* *}$ &, $393^{* *}$ \\
\hline $\begin{array}{c}\text { Opportunities for } \\
\text { Student } \\
\text { Engagement }\end{array}$ &, $603^{* *}$ &, $501^{* *}$ &, $480^{* *}$ &, $596^{* *}$ \\
\hline${ }^{*} \mathrm{p}<0,05$ & & & \\
$* * * 0,01$ & & & \\
\hline
\end{tabular}

Students with a higher grade point average have significantly higher scores on all dimensions of engagement in learning and school climate (except for compliance with rights and responsibilities, where the difference is not significant) than students with a low grade point average. Table 2 presents the means, standard deviations, and differences between the group with high and low grade point average on engagement in learning. Table 3 similarly presents data on students' perceptions of school climate.

Table 2. Means, Standard Deviations and Differences in student engagement in students with high and low grade point averages

\begin{tabular}{|c|c|c|c|c|c|c|}
\hline \multirow[t]{2}{*}{ School engagement } & \multicolumn{2}{|c|}{$\begin{array}{l}\text { Students with low } \\
\text { grade point } \\
\text { average } N=146\end{array}$} & \multicolumn{2}{|c|}{$\begin{array}{l}\text { Students with high } \\
\text { grade point } \\
\text { averageN=143 }\end{array}$} & \multirow[t]{2}{*}{$t$} & \multirow[t]{2}{*}{$p$} \\
\hline & $M$ & $S D$ & $M$ & $S D$ & & \\
\hline Overall result & 102,09 & 20,745 & 121,96 & 19,046 & $-8,463$ & 001 \\
\hline $\begin{array}{l}\text { Behavioural } \\
\text { engagement }\end{array}$ & 35,92 & 8,823 & 44,74 & 7,003 & $-9,367$ & ,001 \\
\hline $\begin{array}{l}\text { Cognitive } \\
\text { engagement }\end{array}$ & 39,53 & 8,585 & 45,03 & 7,857 & $-5,668$ & ,001 \\
\hline $\begin{array}{l}\text { Emotional } \\
\text { engagement }\end{array}$ & 26,64 & 7,171 & 32,51 & 6,537 & $-7,246$ & ,001 \\
\hline
\end{tabular}


Table 3. Means, Standard Deviations and Differences in school climate in students with high and low grade point averages

\begin{tabular}{|c|c|c|c|c|c|c|}
\hline \multirow[t]{2}{*}{ School Climate } & \multicolumn{2}{|c|}{$\begin{array}{l}\text { Students with low } \\
\text { grade point } \\
\text { average } N=146\end{array}$} & \multicolumn{2}{|c|}{$\begin{array}{l}\text { Students with } \\
\text { high grade point } \\
\text { average } N=143\end{array}$} & \multirow[t]{2}{*}{$t$} & \multirow[t]{2}{*}{$p$} \\
\hline & $M$ & $S D$ & $M$ & $S D$ & & \\
\hline Overall result & 130,29 & 27,479 & 149,30 & 24,511 & $-5,667$ & ,001 \\
\hline $\begin{array}{l}\text { Positive Student- } \\
\text { Teacher Relationships }\end{array}$ & 23,46 & 7,574 & 28,34 & 5,913 & $-5,507$ & ,001 \\
\hline School Connectedness & 10,32 & 3,667 & 13,30 & 3,070 & $-6,859$ & ,001 \\
\hline Academic Support & 13,85 & 3,044 & 15,34 & 2,721 & $-3,968$ & ,001 \\
\hline Order and Discipline & 19,51 & 5,457 & 21,97 & 4,668 & $-3,763$ & ,001 \\
\hline $\begin{array}{ll}\text { School } & \text { Physical } \\
\text { Environment } & \end{array}$ & 15,00 & 3,865 & 16,14 & 3,037 & $-2,557$ & ,011 \\
\hline $\begin{array}{ll}\text { School } & \text { Social } \\
\text { Environment } & \end{array}$ & 6,66 & 1,681 & 7,35 & 1,552 & $-2,706$ & ,008 \\
\hline $\begin{array}{l}\text { Perceived } \\
\text { Exclusion/Privilege }\end{array}$ & 8,63 & 2,712 & 8,73 & 2,711 &,- 289 & ,772 \\
\hline Academic Satisfaction & 5,04 & 2,031 & 6,53 & 1,906 & $-5,841$ & ,001 \\
\hline Parental Involvement & 7,95 & 2,937 & 9,25 & 2,675 & $-3,542$ & ,001 \\
\hline $\begin{array}{l}\text { Opportunities for } \\
\text { Student Engagement }\end{array}$ & 20,04 & 5,533 & 22,57 & 4,646 & $-3,843$ & ,001 \\
\hline
\end{tabular}

\section{Discussion of results}

Grade point average is often used as a predictor of student achievement or ability. One of the most important skills teachers possess is the ability to accurately measure student achievement levels and to evaluate them conscientiously and objectively. The teacher is responsible for selecting the content, form and sequence of student evaluations. Evaluation is a complex process that involves making judgments about a student. The most common way to evaluate a student is through a grade, a descriptive rating, or an exam score. Information about student achievement is a key element in motivating students to learn (GwiazdowskaStańczak \& Sękowski, 2018). Renzulli's Triple-Ring Model of Ability lists above-average ability, creativity and work engagement as components of ability (Renzulli, 2005). Thus, the assumption that high academic engagement would translate into high grade point average was correct. Students with high grade point averages have higher scores on all dimensions of academic engagement and school climate except compliance with rights and responsibilities (student rights are the same regardless of school performance). Observance of rights and 
responsibilities means that all students know the rules and privileges and that they are respected. The clearer the rules of responsibility, including for equipment and supplies, the better the students perceive their school. For example, students will be on duty and will be allowed to use the various labs, e.g., the computer room, where everyone knows his or her responsibility for the equipment used. The connection between a high average grade and academic engagement and school climate may be two-sided: on the one hand, the fact that a student gets good grades makes the student more engaged in learning and in attending school, and the student is satisfied with his or her relationship with the teacher; on the other hand, satisfaction with school and engagement may cause the student to get better grades. Many different factors, both internal and external, can influence the development of a child's abilities - the external factors certainly include the school environment and the relationship with teachers and peers in the classroom. Almost all dimensions of school climate are perceived more positively by high-achieving students. Most of them certainly have a twoway impact as well. A good relationship and teacher support motivate better achievement, but a student who learns well and scores the best grades will also be better appreciated and liked in the teacher's perception. The difficult skill for the best educators is to be able to establish positive relationships on an equal basis with all students and to avoid stereotyping on the basis of "bad student" and "good student." As the results of the study indicate, students with higher grade point averages rate their attitude toward school, teachers, and their support better than those with weaker grades. Unfortunately, this is a bit of a vicious circle: those with better grades feel more comfortable at school and have better achievements, while those with lower grades have a poorer school climate, thus lacking the motivation to improve their performance. An important factor in a student's high academic achievement is his or her persistence and activity, which is closely related to academic engagement. (Gwiazdowska-Stańczak \& Sękowski, 2018). Several researchers indicate that gifted students can become so engaged in learning that they can forget to eat and sleep. High achievement is also strongly associated with adequate cognitive strategies, which is nothing more than an element of cognitive engagement (Hesam, \& Abedi, 2020). Other studies have shown how behavioural engagement translates into high school achievement in girls. This study compared the time and places of high and low achieving students and found that the more able students spent more time in libraries and learning activities (Ziegler, Vialle, \& Wimmer, 2013).

A positive student-teacher relationship is one of the most important factors in creating a good school climate. The teacher creates a positive relationship based primarily on good, open communication. Students know that they can approach their teacher with problems, that he/she will have time for them and will listen to and understand them. They see him as someone who is genuinely interested in their concerns and cares about their future. He shows an attitude of openness, helpfulness and well-meaning attention. Through 
the activities undertaken, honest assessment and feedback, the teacher develops in young people their self-esteem. Learning support relates to the actions of the teacher who sets clear expectations. Students understand their homework and assignments in class. They know the requirements of what they need to know for a given grade. The teacher expects all students to do their best, do their homework, study and prepare for class. With the support shown, students feel that they will do well in school (Zullig et al., 2015). Sometimes learning support is often only associated with students who have obvious learning problems. For weaker students, tutoring, remedial classes or extra time may be arranged. It is worthwhile, however, to look at the distribution of gifted and low-achieving students in a given class. Both high- and low-achieving students require teacher attention in order to nurture a passion for learning and a positive perception of the school climate.

\section{Summary}

Engagement in learning is a complex construct that can be influenced by many factors - psychological and social. One of the most important elements that shape students' passion for learning is their teacher. How he or she builds his or her relationship with students, what kind of learning support he or she provides, will have a direct impact on student achievement. This requires dedication, time and self-improvement on the part of teachers, but ultimately it is worth the effort. A greater challenge, for the entire school community, is to create a positive school climate. There are many factors involved, including social relationships and competencies, as well as the building itself and the school environment. The goal of every teacher is for the student to achieve good academic results. It is not always easy to encourage students to learn and to make learning challenging for them. School content may often seem unattractive and unnecessary. Students may not make sense of it or know how what they are learning can be used in their everyday lives. The teacher's goal should be to introduce students to methods that transform school learning into fun and exciting adventures. Engagement in learning and school climate are very important elements that indicate a student's positive attitude towards school and learning, contact with teachers and peers. This article focused on the differences between students with high and low grade point averages and found that students with higher academic achievement have a more positive perception of their school climate and are more engaged in learning.

It is worthwhile to conduct a climate and student engagement diagnostic at your school to identify your school's unique issues. By understanding your school's climate and how students feel about it, you can take measures to ensure improvement. A positive school climate strengthens student engagement in learning, increases student achievement and, most importantly, makes teachers' work better in the classroom. 


\section{Bibliography:}

Clifford, M., Menon, R. Gangi, T. Condon, C., Hornung, K. (2012). Measuring school climate for gauging principal performance: A review of the validity and reliability of publicly accessible measures. American Institutes for Research, Washington.

Daily, S.M., Mann, M.J., Kristjansson, A.L., Smith, M.L., \& Zullig, K.J. (2019). School climate and academic achievement in middle and high school students. Journal of School Health, 89(3), 173-180.

Ferreira, M., Martinsone, B., \& Talić, S. (2020). Promoting sustainable social emotional learning at school through relationship-centered learning environment, teaching methods and formative assessment. Journal of Teacher Education for Sustainability, 22(1), 21-36.

Fredricks, J.A., Filsecker, M., \& Lawson, M. A. (2016). Student engagement, context, and adjustment: Addressing definitional, measurement, and methodological issues.

Gwiazdowska-Stańczak, S. (2021). Zaangażowanie w naukę i klimat w szkole. [School engagement and school climate] Warszawa: Difin.

Gwiazdowska-Stańczak, S., Sękowski, A.E. (2018). Rodzina uczniów zdolnych. [Families of gifted students] Warszawa: Difin.

Hesam, M., \& Abedi, A. (2020). Enhancing academic engagement of underachieving gifted students: The effects of Martin's educational program. Journal of Education and Health Promotion, 9, 137-147.

Holmberg, B. (2020). Guided didactic conversation in distance education. (in:) D. Seward, D. Keegan, B. Holmberg (eds.), Distance education: International perspectives, 114-122, London: Routledge.

Høigaard, R., Kovač, V.B., Øverby, N.C. \& Haugen, T. (2015). Academic Self-Efficacy Mediates the Effects of School Psychological Climate on Academic Achievement. School Psychology Quarterly, 30 (1), 64-74. https://doi.org/10.1037/spq0000056.

Lam, S.F., Jimerson, S., Shin, H., Cefai, C., Veiga, F.H., Hatzichristou, C.\& Zollneritsch, J. (2016). Cultural universality and specificity of student engagement in school: The results of an international study from 12 countries, British Journal of Educational Psychology, 86(1), 137-153.

Liang, C.T.H., Rocchino, G.H., Gutekunst, M.H.C., Paulvin, C., Melo Li, K., \& ElamSnowden, T. (2020). Perspectives of respect, teacher-student relationships, and school climate among boys of color: A multifocus group study. Psychology of Men $\mathcal{E}$ Masculinities, 21(3), 345-356, https://doi.org/10.1037/men0000239

Lippman, L. \& Rivers, A. (2008). Assessing school engagement: A guide for out-of-school time program practitioners. Child Trends, 39, 1-5. 
Malone, M., Cornell, D. \& Shukla, K. (2017). Association of grade configuration with school climate for 7th and 8th grade students. School Psychology Quarterly 32(3), 350-366 https:// doi.org/10.1037/spq0000174.

Martinez, A., Coker, C., McMahon, S.D., Cohen, J., \& Thapa, A. (2016). Involvement in extracurricular activities: Identifying differences in perceptions of school climate. The Educational and Developmental Psychologist, 33(1), 70-84.

Poorthuis, A.M.G., Juvonen, J., Thomaes, S., Denissen, J.J.A., Orobio de Castro, B., \& van Aken, M.A.G. (2015). Do grades shape students' school engagement? The psychological consequences of report card grades at the beginning of secondary school. Journal of Educational Psychology, 107(3), 842-854, https://doi.org/10.1037/edu0000002

Renzulli, J.S. (2005). The Three-Ring Conception of Giftedness. A Developmental Model for Promoting Creative Productivity, (in.) R. J. Sternberg, J.E. Davidson (ed.), Conceptions of Giftedness, 246-279, Cambridge, New York, Melbourne, Madrid, Cape Town, Singapore, São Paulo: Cambridge University Press.

Reyes, M.R., Brackett, M.A., Rivers, S.E., White, M., \& Salovey, P. (2012). Classroom Emotional Climate, Student Engagement, and Academic Achievement. Journal of Educational Psychology. Advance online publication, https:// doi.org/10.1037/a0027268

Sękowski, A.E., Gwiazdowska-Stańczak, S. (2019). Postrzeganie własnej rodziny przez uczniów z wysokimi osiągnięciami szkolnymi, Przegląd Psychologiczny, 62(2), 249-265.

Skinner, E.A., Pitzer, J.R., \& Steele, J.S. (2016). Can student engagement serve as a motivational resource for academic coping, persistence, and learning during late elementary and early middle school?. Developmental Psychology, 52(12), 2099.

Ziegler, A., Vialle, W., Wimmer, B. (2013). The actiotope model of giftedness: An introduction to some central theoretical assumptions, (in.): S.N. Phillipson, H. Stoeger, A. Ziegler (ed.) Exceptionality in East Asia: Explorations in the actiotope model of giftedness, 1-17, London: Routledge.

Zullig, K.J., Collins, R., Ghani, N., Patton, J.M., Hunter, A.A. \& Scott Huebner, E., (2014). Preliminary Development of a Revised Version of the School Climate Measure. Psychological Assessment, 27 (3), 1072-1081. http:/ / dx.doi.org/10.1037/ pas0000070. 